ZOOLOGIA 31 (5): 475-481, October, 2014

http://dx.doi.org/10.1590/S1984-46702014000500007

\title{
The sea anemone Bunodactis octoradiata (Anthozoa: Actiniaria) from southern Patagonia: morphological study and new records
}

\author{
Agustín Garese',3, María V. Longo', Juan P. Martin² \& Fabián H. Acuña ${ }^{1}$ \\ ${ }^{1}$ Instituto de Investigaciones Marinas y Costeras (IIMyC), Facultad de Ciencias Exactas y Naturales, CONICET, Universidad \\ Nacional de Mar del Plata. Funes 3250, 7600 Mar del Plata, Argentina. \\ 2 Unidad Académica San Julián, Universidad Nacional de la Patagonia Austral, Colón y Sargento Cabral. 9310 Puerto San \\ Julián, Santa Cruz, Argentina. \\ ${ }^{3}$ Corresponding author. E-mail: agarese@mdp.edu.ar
}

\begin{abstract}
Bunodactis Verril, 1899 comprises at present 19 nominal species of sea anemones. The validity of the genus is under discussion. The description of the species, Bunodactis octoradiata Carlgren, 1899, is insufficient for reliable identification, and although subsequent works have provided additional information on the species, its description still needs to be complemented. Herein we describe $B$. octoradiata based on histological sections of the internal anatomy, and give a complete and detailed description of the external anatomy. The cnidom is composed of spirocysts, basitrichs and microbasic p-mastigophores; their distribution in the organism, sizes and relative abundances are provided. The presence of zooxanthellae is reported for the first time. Bunodactis octoradiata is distributed in groups that vary from 5.6 to 45 ind. $/ \mathrm{m}^{2}$ in the field. Additionally, our data extends the distribution of the species along the coast of southern Patagonia ( $47^{\circ} 44^{\prime} 36^{\prime \prime}-49^{\circ} 15^{\prime} 13^{\prime \prime} S$ and $\left.65^{\circ} 50^{\prime} 26^{\prime \prime}-67^{\circ} 39^{\prime} 45^{\prime \prime} \mathrm{W}\right)$.
\end{abstract}

KEY WORDS. Actiniidae; cnidom; spatial distribution; taxonomy.

Bunodactis Verril, 1899 (Anthozoa: Actiniidae) comprises many nominal species whose validity and generic assignment are not known with certainty and need confirmation. The validity of the genus has also been questioned. Carlgren (1949) synonymized Bunodactis with Aulactinia Verrill, 1864, as he placed the type species, Aulactinia capitata Agassiz in Verrill, 1864, in Bunodactis. Subsequently, Dunn et al. (1980) indicated that Aulactinia has priority over Bunodactis and, accordingly, should be the valid generic name. Recently, Spano et al. (2013), in the re-description of Bunodactis hemaphroditica (Carlgren, 1959), discussed the nomenclature of these genera. They pointed out that the synonymization of the two genera only occurred because Carlgren (1949) placed the type species of Aulactinia in Bunodactis. Thus, they still consider Bunodactis as valid until Aulactinia is revised, including its type material. In this study, we follow Spano et al. (2013) and consider Bunodactis as valid.

Two species of Bunodactis have previously been described from Patagonia; B. patagoniensis (Carlgren, 1899) from Puerto Madryn ( $42^{\circ} 46^{\prime} \mathrm{S}, 65^{\circ} 02^{\prime} \mathrm{W}$, Chubut Province, Argentina) and B. octoradiata (Carlgren, 1899), which is distributed in the southern most regions of Argentina and Chile (Tierra del Fuego and Straits of Magellan) and around the Malvinas/Falklands Island. The original description of $B$. octoradiata is incomplete because it does not depict characteristics of the internal anatomy and the cnidae. Although subsequent descriptions have provided some missing information (CARLGREN 1927, 1959), a detailed study of the cnidom with images, biometry and abundance of cnidocysts, histological section of its internal anatomy, characteristics of male gametogenic tissue and ecological data of spatial distribution are still lacking. The aims of this work were to study the morphology of $B$. octoradiata, to provide new distribution records for it and to add information on its spatial distribution and density in the intertidal zone.

\section{MATERIAL AND METHODS}

During December 2009 and March 2010, a total of 114 specimens of Bunodactis octoradiata were collected from the following localities (Fig. 1) of Santa Cruz Province (southern Patagonia, Argentina): Península Foca $\left(47^{\circ} 44^{\prime} 366^{\prime \prime}\right.$, $65^{\circ} 50^{\prime}$ $\left.26^{\prime \prime} \mathrm{W}\right)$, Playa La Mina $\left(49^{\circ} 09^{\prime} 23^{\prime \prime} \mathrm{S}, 67^{\circ} 37^{\prime} 46^{\prime \prime} \mathrm{W}\right)$, Cabo Curioso $\left(49^{\circ} 12^{\prime} 11^{\prime \prime S}, 67^{\circ} 39^{\prime} 45^{\prime \prime} \mathrm{W}\right)$, Punta Cueva $\left(49^{\circ} 13^{\prime} 10^{\prime \prime} \mathrm{S}, 67^{\circ} 40^{\prime}\right.$

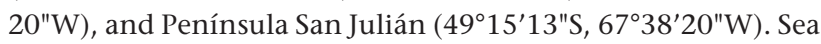
water temperature from these areas oscillates between $5^{\circ} \mathrm{C}$ (winter) and $14^{\circ} \mathrm{C}$ (summer) and the region is considered to have cold waters of sub-Antarctic origin. All specimens were collected from the intertidal zone, anesthetized with $\mathrm{MgCl}_{2}$ and then fixed in 5\% seawater formalin and preserved in 70\% ethanol. For histology, four specimens of B. octoradiata were embedded in paraffin, sectioned at $5 \mu \mathrm{m}$ and stained with hematoxylin-eosin or Masson trichrome. Cnidae from 4 specimens were measured using a microscope with a micrometric

2014 Sociedade Brasileira de Zoologia | www.sbzoologia.org.br | www.scielo.br/zool All content of the journal, except where identified, is licensed under a Creative Commons attribution-type BY-NC. 


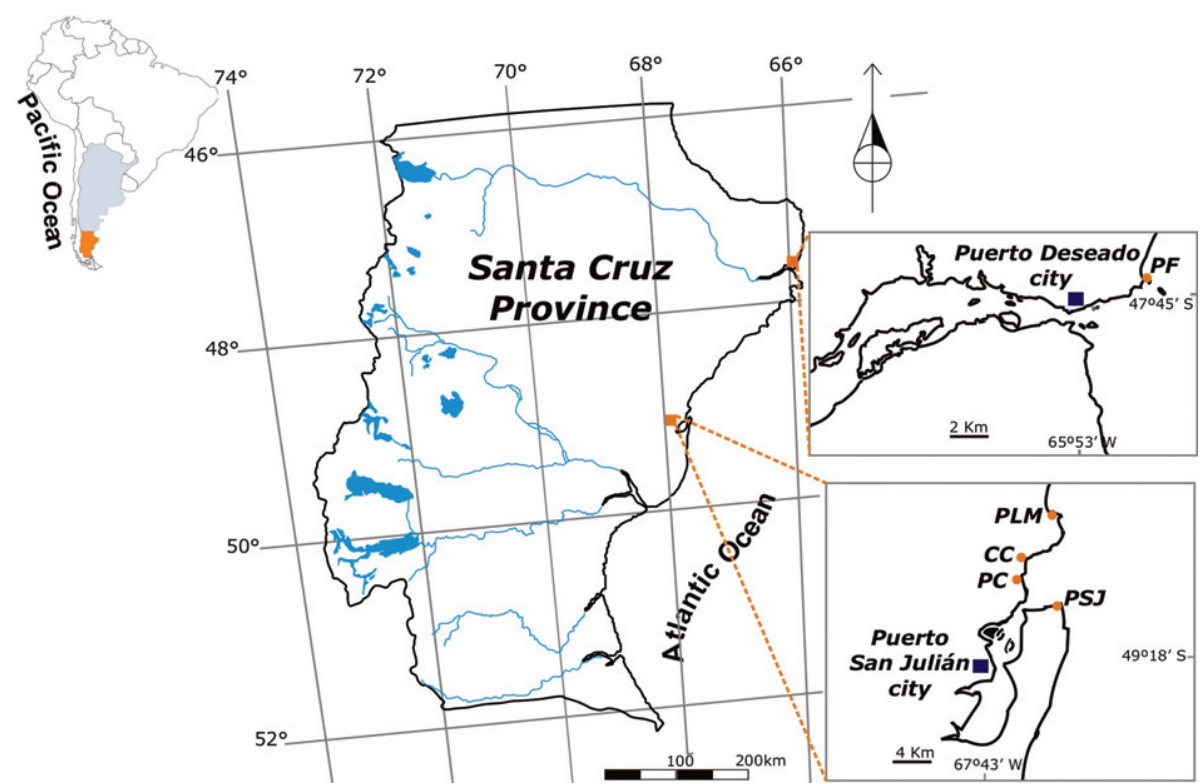

Figure 1. Sampling sites along the coast of Santa Cruz Province (Southern Patagonia, Argentina). Península Foca (PF), Punta Cueva (PC), Cabo Curioso (CC), Playa La Mina (PLM), Península San Julián (PSJ).

eyepiece at 1000X (oil immersion). From each individual, 40 unfired capsules were measured per type and tissue. Nematocysts nomenclature follows EnGLAND (1991).

Five specimens are deposited at the Actiniarian Collection of the Departamento de Ciencias Marinas (Facultad de Ciencias Exactas y Naturales, Universidad Nacional de Mar del Plata), with reference number C.A. 29.

The density of individuals of the species was estimated on the intertidal zone of Cabo Curioso. The sampling was carried out in transects at four stations, separated from each other by $50 \mathrm{~m}$, from the middle intertidal to the lower intertidal zones. At each station, ten samples were taken using a quadrant (size: $40 \times 40 \mathrm{~cm}$ ), noting the number of specimens found to calculate density. Then, to establish the spatial distribution in the field we calculated the patchiness index as the relationship between variance and media $\left(s^{2} / \bar{x}\right)$. If the values of this relationship close to 1 , the distribution was considered aleatory; values of zero or close to zero indicated a uniform distribution, and values greater than 1 suggested that the distribution of the organism was grouped (Southwood 1978).

\section{TAXONOMY}

\section{Bunodactis octoradiata (Carlgren, 1899)}

Bunodes octoradiatus Carlgren, 1899: 20-21.

Cibrina octoradiata: Clubb, 1908: 7-8.

Bunodactis octoradiata: Pax, 1923: 26; Carlgren, 1927: 30-31; 1959: 22-23.

Aulactinia octoradiata: Rodríguez et al., 2007: 1879, 1890, 1899.
External anatomy. In preserved specimens, height of column is usually $12 \mathrm{~mm}$ (up to $19 \mathrm{~mm}$ ), diameter of pedal disc is broadly $12 \mathrm{~mm}$ (up to $14 \mathrm{~mm}$ ), diameter of oral disc up to 10 $\mathrm{mm}$. The oral disc is dark red to black with visible mesenterial insertions, with a yellow annulus around the mouth, and 28 to 32 red tentacles arranged in three cycles (Fig. 2). The column is red, sometimes purple-colored distally. Whitish to pinkish verrucae, all about the same size, sparser in the nearest zone to pedal disc, irregularly arranged in approximately 30 vertical rows. They have foreign material such as shell remains, sand, gravel and algae attached (Fig. 5). On the margin of the column there are non-adhesive blister-shaped protuberances, clearly visible in preserved specimens, called here marginal projections. The color is very stable and very distinctive in this species, allowing easy field identification. Pedal disc well developed, more or less circular, with lightly scalloped edge in fixed material.

Internal anatomy. Actinopharynx deeply furrowed, with two well-developed siphonoglyphs. 16 pairs of perfect mesenteries arranged in two cycles $(8+8)$ (Fig. 6); this arrangement is constant throughout the body with the same number of mesenteries distally and proximally. Retractor muscles diffuse, restricted and strong; parietobasilar muscles very strong with short free flap (Fig. 6); basilar muscles strong. Marginal sphincter muscle endodermal, circumscript and palmate (Fig.7). Longitudinal muscles of tentacles ectodermal (Fig. 8). Specimens with reproductive tissues were all males with all mesenteries fertile, in which spermatogenic follicles were observed (Figs 9 and 10). In mesenterial filaments the cnidoglandular, ciliated and reticular tracts are easily distinguishable (Fig. 11). Simple verrucae at 

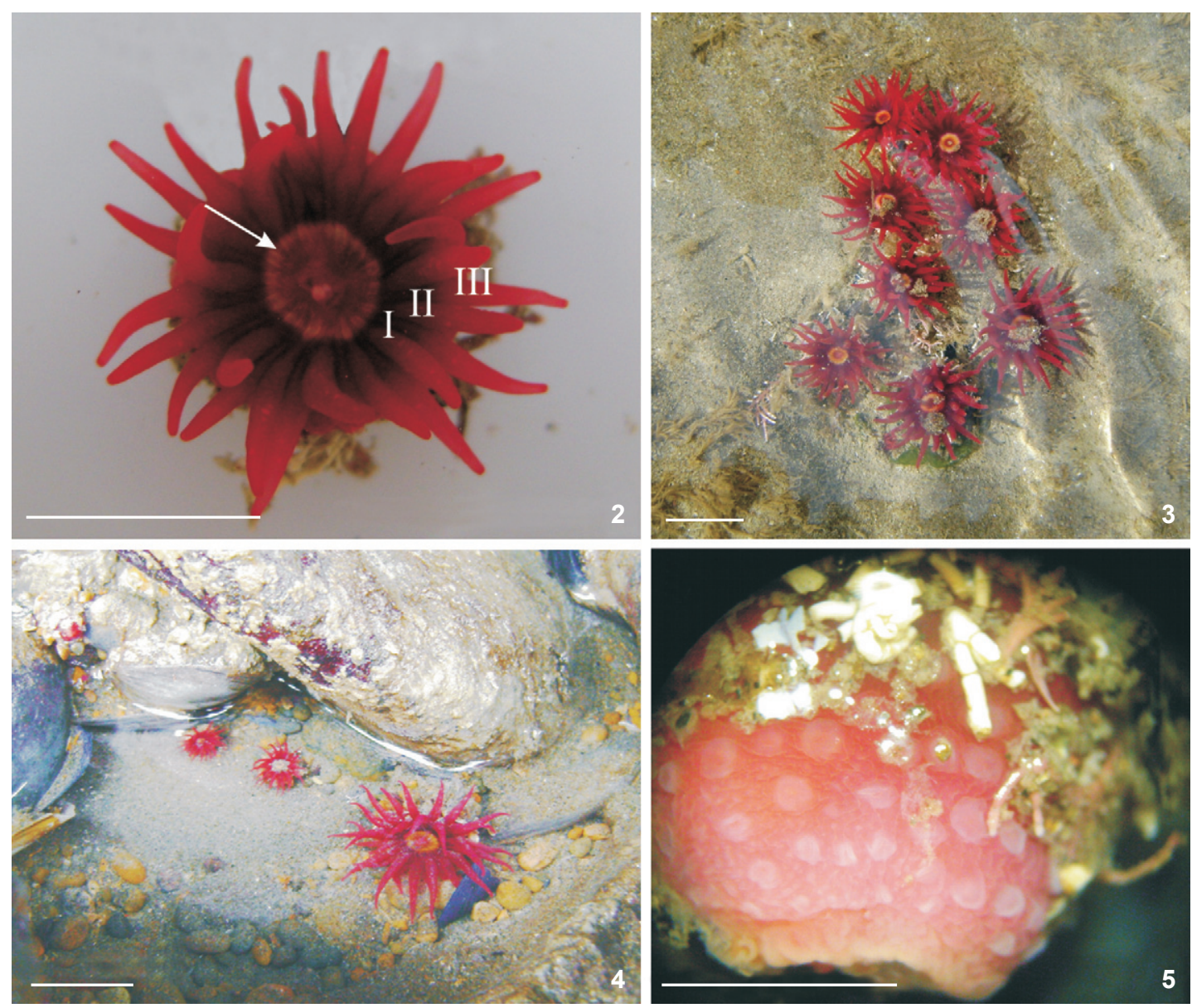

Figures 2-5. Bunodactis octoradiata: (2) oral view (arrow: yellow annulus; I, II and III: $1^{\text {st }}$ to $3^{\text {rd }}$ cycle of tentacles); (3) aggregation of individuals in situ; (4) individuals in a tide pool; (5) lateral view of column showing the verrucae and attached material. Scale bars: $10 \mathrm{~mm}$.

column, both endocoelic and exocoelic (Fig. 12). Zooxanthellae with mean diameter of approximately $5 \mu \mathrm{m}$ were observed in the endoderm of tentacles, but they were not found in other structures of specimens. This is the first time that their presence has been reported in this species (Fig. 8).

Cnidom. Spirocysts (Fig. 13), basitrichs (Figs 14-17, 1920 and 22-23) and microbasic p-mastigophores (Figs 18 and 21) comprise the cnidom of $B$. octoradiata. See Table I for distribution, size and abundance of cnidae. All types have representative abundances in respective structures; the cnidom is qualitatively very similar between structures with the exception of spirocysts that are found only in tentacles. We also analyzed the cnidom in marginal projections. They had the same types of cnidocysts with similar sizes and abundances as in the rest of the column.

Ecological aspects. In the present study, B. octoradiata was found on rocky shores of the cities of Puerto Deseado and Puerto San Julián (Fig. 1). It is a common species in the inter- tidal zones, inhabiting both exposed and protected areas, and shares habitat with other common sea anemones such as Antholoba achates (Drayton in Dana, 1846) and Metridium senile (Carlgren, 1899). Individuals of $B$. octoradiata were frequently found aggregated (Fig. 3), and usually in particular microhabitats such as crevices and tide pools (Fig. 4). Column is cover with remains of shells, sand, gravel and algae (Fig. 5). The abundance of B. octoradiata in Cabo Curioso was high from the middle intertidal to the initiation of lower intertidal (stations 1 to 3 ) and declined drastically to the lowest zone of the lower intertidal (station 4) on the border with the subtidal. The mean density was: 45 individuals per $\mathrm{m}^{2}(\mathrm{sd}=45.5)$ at station $1 ; 35.6$ individuals per $\mathrm{m}^{2}(\mathrm{sd}=26)$ at station $2 ; 43.75$ individuals per $\mathrm{m}^{2}(\mathrm{sd}=21.87)$ at station 3 , and 5.6 individuals per $\mathrm{m}^{2}(\mathrm{sd}=7.43)$ at station 4 . The values of the relationship between variance and media were 46 for station $1 ; 19$ for station 2; 10.9 for station 3, and 9.8 for station 4 ; all cases indicated a grouped distribution of the species in the field. 

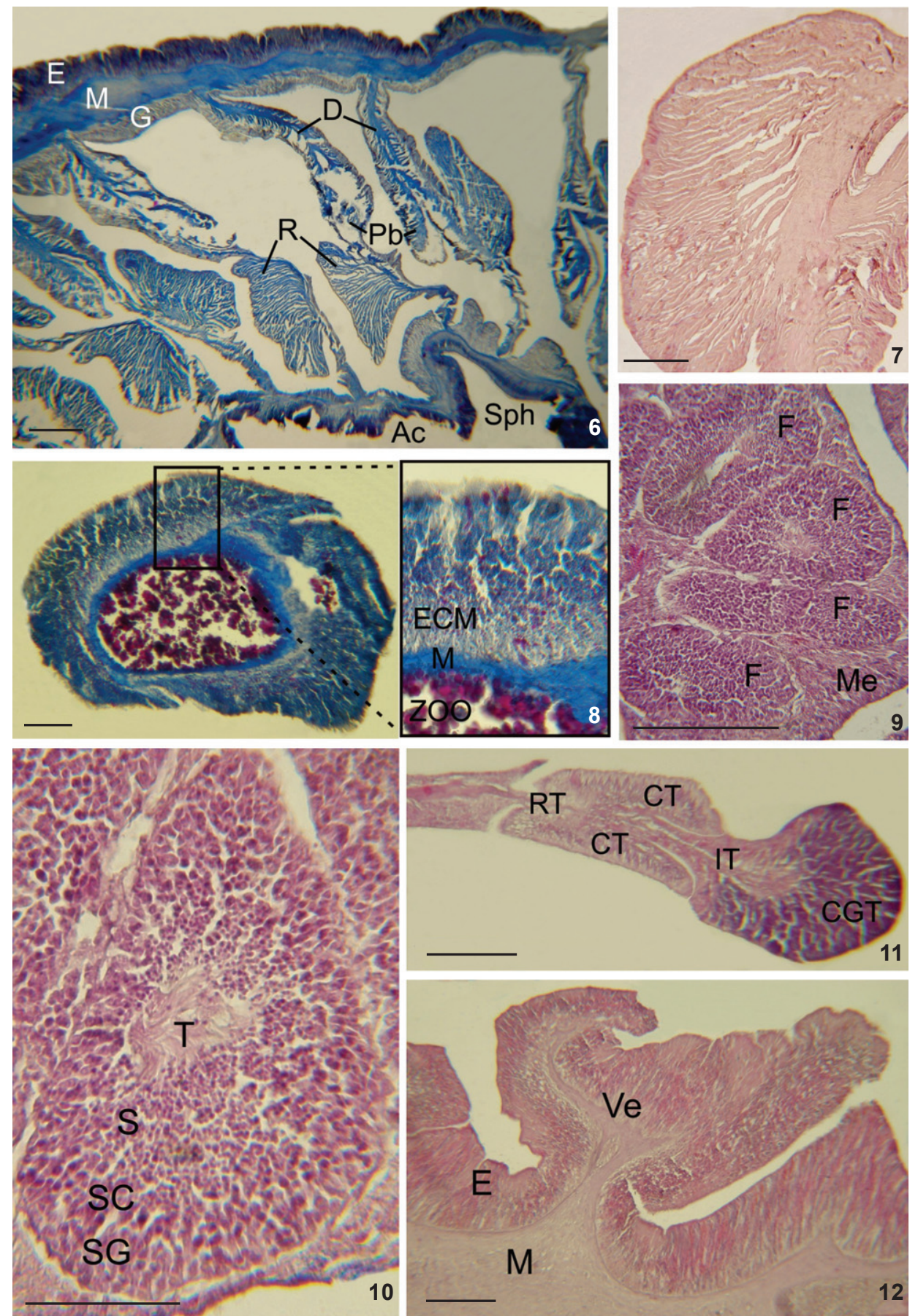

Figures 6-12. Bunodactis octoradiata internal anatomy: (6) cross section through the column proximal to the actinopharynx (Ac) (D: directive mesenteries, E: ectoderm, G: gastrodermis, M: mesoglea, Pb: parietobasilar muscles, R: retractor muscles, Sph: siphonoglyph); (7) circumscribed palmate sphincter in longitudinal section, (8) tentacle cross section showing ectodermic muscles (ECM) and zooxanthellae (ZOO); (9) fertile mesentery with spermatogenic follicles (F) (Me: mesentery); (10) Spermatogenic follicles detail (S: spermatozoids, SC: spermatocytes, SG: spermatogonia, T: tales of spermatozoids); (11) mesenterial filament (CGT: cnidoglandular tract, CT: ciliar tract, IT: intermediate tract, RT: reticular tract); (12) longitudinal section of the column showing a verrucae (Ve) (E: ectoderm, M: mesoglea). Scale bars: $6=200 \mu \mathrm{m}, 7=100 \mu \mathrm{m}, 8=100 \mu \mathrm{m}, 9=50 \mu \mathrm{m}, 10=50 \mu \mathrm{m}, 11=100 \mu \mathrm{m}, 12=200 \mu \mathrm{m}$. 

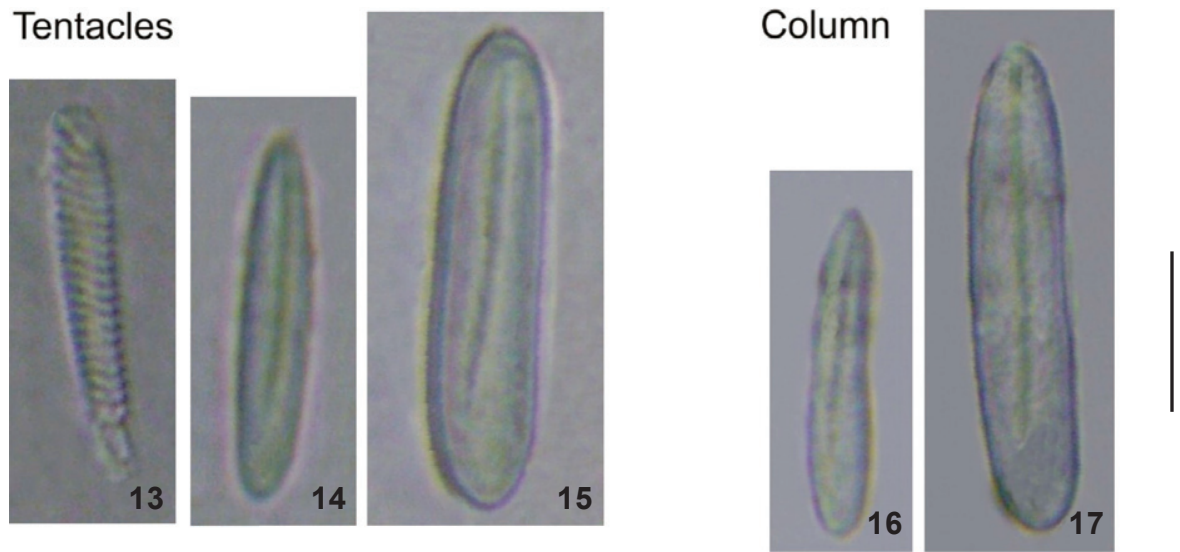

\section{Actinopharynx}
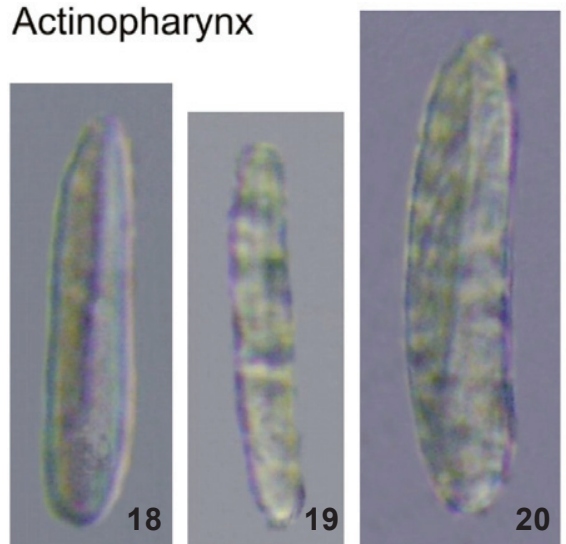

\section{Mesenterial filaments}

Figures 13-23. Cnidom of Bunodactis octoradiata: (13) spirocyst; $(14,16,19,22)$ basitrich I; $(15,17,20,23)$ basitrich II; $(18,21)$ microbasic p-mastigophore. Scale bar: $10 \mu \mathrm{m}$.

Table I. Distribution and size of cnidae of Bunodactis octoradiata. Range, length and width (sd = standard deviation). N: total number of measured cnidocysts. Ratio: proportion of number of specimens in which each cnida was found over the number of specimens examined. Abundance: $(+)$ rare, $(++++)$ very common.

\begin{tabular}{|c|c|c|c|c|c|c|}
\hline Tissue and Cnida type & $\begin{array}{c}\text { Length }(\mu \mathrm{m}) \\
(\min -\mathrm{max}) \text { mean } \pm \mathrm{sd}\end{array}$ & $\begin{array}{c}\text { Width }(\mu \mathrm{m}) \\
(\min -\mathrm{max}) \text { mean } \pm \mathrm{sd}\end{array}$ & $\mathrm{N}$ & Ratio & Abundance & $\begin{array}{c}\text { Range mentioned by CARLGReN }\left(1927^{*}, 1959\right) \\
\text { length } x \text { width }(\mu \mathrm{m})\end{array}$ \\
\hline \multicolumn{7}{|l|}{ Tentacles } \\
\hline Spirocyst & $(18-30) 24.40 \pm 3.32$ & $(3-4) 3.10 \pm 0.30$ & 40 & $4 / 4$ & ++++ & $(14-26) \times(1-2.5)$ \\
\hline Basitrich I & (17-27) $19.82 \pm 1.66$ & $(2-4) 3.05 \pm 0.31$ & 40 & $4 / 4$ & +++ & $(14-17) \times(3.5)$ \\
\hline Basitrich II & $(25-32) 28.62 \pm 1.77$ & $(5-7) 5.37 \pm 0.54$ & 40 & $4 / 4$ & ++ & $(21-26) \times(5-6.3)$ \\
\hline \multicolumn{7}{|l|}{ Column } \\
\hline Basitrich I & $(11-20) 15.57 \pm 1.72$ & $(2-3) 2.95 \pm 0.38$ & 40 & $4 / 4$ & ++++ & $(13.4-18) \times(-)$ \\
\hline Basitrich II & $(23-34) 28.70 \pm 2.67$ & $(4-8) 5.67 \pm 0.76$ & 40 & $4 / 4$ & +++ & $(21-32.4) \times(5-8.5)$ \\
\hline \multicolumn{7}{|l|}{ Actinopharynx } \\
\hline Microbasic p-mastigophore & $(21-27) 24.37 \pm 1.46$ & $(3-5) 4.15 \pm 0.42$ & 40 & $4 / 4$ & ++++ & $(18.3-21.8) \times(3.5-4.2)$ \\
\hline Basitrich I & $(17-26) 20.30 \pm 2.13$ & $(2-5) 3.12 \pm 0.51$ & 40 & $4 / 4$ & +++ & - \\
\hline Basitrich II & $(26-40) 32.20 \pm 3.33$ & $(4-9) 4.95 \pm 1.06$ & 40 & $4 / 4$ & +++ & $(24-31) \times(4.2-7)$ \\
\hline \multicolumn{7}{|l|}{ Filament } \\
\hline Microbasic p-mastigophore & $(21-30) 26.00 \pm 2.03$ & $(3-5) 4.12 \pm 0.51$ & 40 & $4 / 4$ & ++++ & $(22.6-25.4) \times(4.2)$ \\
\hline Basitrich I & $(18-23) 20.62 \pm 1.61$ & $(3-4) 3.02 \pm 0.15$ & 40 & $4 / 4$ & ++++ & $(17-19.7) \times(2.8-3)$ \\
\hline Basitrich II & (26-39) $29.50 \pm 2.70$ & $(3-6) 4.62 \pm 0.62$ & 40 & $4 / 4$ & ++++ & $(21-27.5) \times(4.2-6.5)$ \\
\hline
\end{tabular}

* Only spirocysts. 


\section{DISCUSSION}

Bunodactis octoradiata has been previously recorded from several localities from the southernmost end of South America (Chile and Argentina). We extend its geographical distribution range northwards, over the coast of Santa Cruz Province in the region of Puerto San Julián City and Puerto Deseado City, Argentina. Thus, B. octoradiata is distributed between $47^{\circ} 44^{\prime} 36^{\prime \prime}-$ $59^{\circ} 15^{\prime} 29^{\prime \prime} \mathrm{S}$ and $60^{\circ} 42^{\prime} 20^{\prime \prime}-71^{\circ} 55^{\prime} 19^{\prime \prime} \mathrm{W}$. In Table II all localities and coordinates are detailed.

There is controversy about the validity of Aulactina and Bunodactis. Carlgren (1949) placed the type species of Aulactinia, A. capitata Agassiz in Verrill, 1864 in Bunodactis, stating that Bunodactis was valid. However, members of Bunodactis never have holotrichs in the marginal structures (CARLgREN 1949) or in the column (ENGLAND 1987), as seen in the analyzed specimens in the current study. Afterwards, Dunn et al. (1980) pointed out that the character that distinguishes Aulactinia from Bunodactis, as defined by CARLGREN (1949), is only the presence of holotrichs (mentioned as atrichous) in the outer tentacles. DunN et al. (1980) broadened the generic definition to include both previous taxa, instead of creating a new taxon, and used Aulactinia as the senior synonym.

On the other hand, SPANo et al. (2013) noted that the controversy between these genera was caused by CARLGREN (1949), who placed the type species of Aulactinia in Bunodactis, and also that the replacement of DunN et al. (1980) was carried out without examining the type-material of Aulactinia. Thus, they consider Bunodactis as still valid until Aulactinia is revised by including its type material. We agree with Spano et al. (2013) and thus use the generic name Bunodactis in this study, and we also consider that the synonymization with Aulactinia is an unsolved problem that requires further comprehensive studies, which should include morphological and molecular characters obtained from the greatest possible number of species of the two genera in order to solve this controversy.

The presence of zooxanthellae in B. octoradiata had not been previously reported, and can be considered unusual for a relatively cold-water species such as this sea anemone. Regarding the cnidae, CARLGReN (1927) measured the size of the nematocysts from all tissues of $B$. octoradiata, with the exception of the mesenterial filaments, pointing out two types in the column, one type in the tentacles and two types in the actinopharynx, but he did not discriminate these into different morphological types. Additionally, CarLgren (1927) also identified and measured spirocysts in the tentacles. Subsequently, Carlgren (1959) identified the types of nematocysts from the different structures and provided their size ranges; these are compared in Table I with the cnidom described in the current study. The size ranges (length and width) of all types of cnidocysts in this study are similar but broader when compared to those found by CARLGREN $(1927,1959)$. Furthermore, with regard to the composition of cnidae, the current results are similar except that we were able to identify two types of basitrichs from the actinopharynx whereas CARLGREN (1959) mentioned only one.

Table II. Distribution of Bunodactis octoradiata.

\begin{tabular}{|c|c|c|}
\hline Locality & Coordinates & Source \\
\hline Península Foca & $47^{\circ} 44^{\prime} 36^{\prime \prime} \mathrm{S}, 65^{\circ} 50^{\prime} 26^{\prime \prime} \mathrm{W}$ & This work \\
\hline Playa La Mina & $49^{\circ} 09^{\prime} 23^{\prime \prime S}, 67^{\circ} 37^{\prime} 46^{\prime \prime} \mathrm{W}$ & This work \\
\hline Cabo Curioso & $49^{\circ} 12^{\prime} 11^{\prime \prime S}, 67^{\circ} 39^{\prime} 45^{\prime \prime} \mathrm{W}$ & This work \\
\hline Punta Cueva & $49^{\circ} 13^{\prime} 10^{\prime \prime} \mathrm{S}, 67^{\circ} 40^{\prime} 20^{\prime \prime} \mathrm{W}$ & This work \\
\hline Península San Julián & $49^{\circ} 15^{\prime} 13^{\prime \prime} \mathrm{S}, 67^{\circ} 38^{\prime} 20^{\prime \prime} \mathrm{W}$ & This work \\
\hline Caubunco & $53^{\circ} 01^{\prime} 40^{\prime \prime} \mathrm{S}, 70^{\circ} 49^{\prime} 12^{\prime \prime} \mathrm{W}$ & Sebens \& Paine (1978) \\
\hline Punta Arenas & $53^{\circ} 10^{\prime} 48^{\prime \prime} \mathrm{S}, 70^{\circ} 55^{\prime} 18^{\prime \prime} \mathrm{W}$ & Carlgren $(1899,1959)$ \\
\hline Punta Santa María & $53^{\circ} 22^{\prime} 36^{\prime \prime} \mathrm{S}, 70^{\circ} 57^{\prime} 06^{\prime \prime} \mathrm{W}$ & Carlgren (1959) \\
\hline Smyth Channel Isthmus Bay & $53^{\circ} 28^{\prime} 38^{\prime \prime} \mathrm{S}, 70^{\circ} 43^{\prime} 12^{\prime \prime} \mathrm{W}$ & Carlgren (1899) \\
\hline Strait of Magellan & $53^{\circ} 30^{\prime} 06^{\prime \prime} \mathrm{S}, 70^{\circ} 42^{\prime} 10^{\prime \prime} \mathrm{W}$ & Carlgren (1899) \\
\hline Port Bulnes & $53^{\circ} 37^{\prime} 44^{\prime \prime} \mathrm{S}, 70^{\circ} 55^{\prime} 10^{\prime \prime} \mathrm{W}$ & Sebens \& Paine (1978) \\
\hline Port Hambre & $53^{\circ} 37^{\prime} 13^{\prime \prime} \mathrm{S}, 70^{\circ} 55^{\prime} 48^{\prime \prime} \mathrm{W}$ & Sebens \& Paine (1978) \\
\hline Port Gallant & $53^{\circ} 44^{\prime} 30^{\prime \prime} \mathrm{S}, 71^{\circ} 55^{\prime} 19^{\prime \prime} \mathrm{W}$ & Carlgren (1899) \\
\hline New Year Island & $54^{\circ} 43^{\prime} 33^{\prime \prime} \mathrm{S}, 64^{\circ} 07^{\prime} 22^{\prime \prime} \mathrm{W}$ & Carlgren (1927) \\
\hline Staten Island & $54^{\circ} 46^{\prime} 15^{\prime \prime} \mathrm{S}, 64^{\circ} 16^{\prime} 22^{\prime \prime} \mathrm{W}$ & Carlgren (1899) \\
\hline Beagle Channel, Lapataia Nueva & $54^{\circ} 49^{\prime} 42^{\prime \prime} \mathrm{S}, 68^{\circ} 34^{\prime} 10^{\prime \prime} \mathrm{W}$ & (Carlgren, 1899) \\
\hline Navarino Island, Puerto Toro & $55^{\circ} 04^{\prime} 27^{\prime \prime} \mathrm{S}, 67^{\circ} 04^{\prime} 15^{\prime \prime} \mathrm{W}$ & (Carlgren, 1899) \\
\hline Saddle Island & $55^{\circ} 31^{\prime} 19^{\prime \prime} \mathrm{S}, 68^{\circ} 04^{\prime} 38^{\prime \prime} \mathrm{W}$ & (Dana, 1846) \\
\hline Lennox Island & $59^{\circ} 15^{\prime} 29^{\prime \prime} \mathrm{S}, 67^{\circ} 04^{\prime} 12^{\prime \prime} \mathrm{W}$ & (Carlgren, 1899) \\
\hline
\end{tabular}

ZOOLOGIA 31 (5): 475-481, October, 2014 
The presence of marginal projections was previously mentioned by CARLgReN $(1899,1927)$ as pseudo-marginal-spherules. Firstly (1899) he stated that nematocysts were more numerous in these structures than in the rest of the column; however, after carrying out new examinations he (1927) found that the cnidom of the spherules and other parts of the column were the same, in agreement with our results. The marginal projections were described by DALY (2003) as permanent, fingerlike projections, with histology and cnidom identical to those of the column, with function unknown. All examined specimens in this study were males, but CARLGREN (1927) mentioned the presence of large ova rich in yolk, and cited ClubB (1908), who found embryos developing in external brood-chambers. Undoubtedly the reproductive biology of this sea anemone is a very interesting topic to be studied in the future, along with other aspects such as the fauna and flora attached to its column and its trophic ecology.

\section{ACKNOWLEDGEMENTS}

This work was funded by grants to F.H.A. (PIP N0011, Consejo Nacional de Investigaciones Científicas y Técnicas and EXA 648/14, Universidad Nacional de Mar del Plata). We are very grateful to James D. Reimer (MISE, University of the Ryukyus) for his help with the English version and comments that greatly improved this manuscript. Special thanks to Karen Sanamyan and an anonymous reviewer for their constructive comments and suggestions.

\section{LITERATURE CITED}

Carlgren, O. 1899. Zoantharien. Hamburger Magalhaensische Sammelreise 4 (1): 1-48.

Carlgren, O. 1927. Actiniaria and Zoantharia. Further Zoological Results of the Swedish Antarctic Expedition 190119032 (3): 1-102.

Carlgren, O. 1939. Actiniaria and Zoantharia of the Scottish National Antarctic Expedition, 1902-1904. Transactions of the Royal Society of Edinburgh 49 (3): 791-800.

Carlgren, O. 1949. A survey of the Ptychodactiaria, Corallimorpharia and Actiniaria. Kungliga Svenska Vetenskapsakadamiens Handlingar 1: 1-122.

Carlgren, O. 1959. Reports of the Lund University Chile Expedition 1948-49, Corallimorpharia and Actiniaria with description of a new genus and species from Peru. Kungliga Svenska Vetenskapsakademiens Handlingar 71 (6): 1-39. Clubb, J.A. 1908. Coelentera. IV. Actiniae. National Antarctic Expedition, Natural History (Zoology) 4: 1-12.

DALY, M. 2003. the anatomy, terminology, and homology of acrorhagi and pseudoacrorhagi in sea anemones. Zoologische Verhandelingen 345: 89-101.

DANA, J.D. 1846. Zoophytes. Volume VII of the Unites States Exploring Expedition. Philadelphia, Lean and Blanchard, 740p.

Dunn, D.F.; Fu-S. Chia \& R. Levine. 1980. Nomenclature of Aulactinia (= Bunodactis), with description of Aulactinia incubans n. sp.(Coelenterata: Actiniaria), an internally brooding sea anemone from Puget Sound. Canadian Journal of Zoology 58 (11): 2071-2080. doi: 10.1139/z80-284

England, K.W. 1987. Certain Actiniaria (Cnidaria, Anthozoa) from the Red Sea and tropical Indo-Pacific. Bulletin of the British Museum (Natural History) 53: 205-292.

ENGLAND, K.W. 1991. Nematocysts of sea anemones (Actiniaria, Ceriantharia and Corallimorpharia: Cnidaria): nomenclature. Hydrobiologia 216/217: 691-697. doi: 10.1007/978-94-0113240-4_97.

PAX, F. 1923. Antarktische Aktinien aus der Ausbeute des "Pourquoi pas". Zoologische Jahrbuecher. Abteilung für Systematic Ökologie und Geographie der Tiere 47: 1-28.

Rodríguez, E.; P.J. López-GonzÁlez \& J.M. Gili. 2007. Biogeography of Antarctic Sea Anemones (Anthozoa, Actiniaria): What do they tell us about the origin of the Antarctic Benthic Fauna. Deep-sea Research II 54 (16-17): 1876-1904. doi: 10.1016/j.dsr2.2007.07.013.

Sebens, K.P. \& R.T. Paine. 1978. Biogeography of anthozoans along the west coast of South America: habitat, disturbance, and prey availability, p. 219-238. In: Proceedings of the International Symposium on Marine Biogeography and Ecology in the Southern Hemisphere. Auckland, N.Z.D.S.I.R.

Spano, C.; N. Rozbaczylo; V. Häussermann \& R. Bravo. 2013. Redescription of the sea anemones Anthopleura hermaphroditica and Bunodactis hermafroditica (Cnidaria: Anthozoa: Actiniaria) from Chile. Revista de Biología Marina y Oceanografía 48 (3): 521-534. doi: 10.4067/S0718-19572013000300010

Southwood, T.R.E. 1978. Ecological methods. London, Chapman \& Hall, 524p.

Submitted: 07.V.2014; Accepted: 07.IX.2014.

Editorial responsibility: Rosana M. da Rocha 